\title{
DNA Barcoding on Cardinalfishes (Apogonidae) of Thoothukudi Coast
}

\author{
R. Rajeshkannan ${ }^{*}$, J. Jaculine Pereira ${ }^{2}$, K. Karal Marx³, P. Jawahar², \\ D. Kiruthiga Lakshmi ${ }^{2}$ and Devivaraprasad Reddy ${ }^{4}$ \\ ${ }^{1}$ Dr. M.G.R. Fisheries College and Research Institute, Ponneri-601204, India \\ ${ }^{2}$ Fisheries College and Research Institute, Thoothukudi-628008, India \\ ${ }^{3}$ Institute of Fisheries Post Graduate Studies, OMR Campus, Vanniyanchavadi-603103, India \\ ${ }^{4}$ Fisheries, Y.S.R. Horticulture University, Andhra Pradesh, India \\ *Corresponding author
}

\begin{tabular}{|l|}
\hline Ke y w o r d s \\
Apogonids, DNA \\
barcoding, \\
Cardinalfishes, Gulf of \\
Mannar, Tuticorin, \\
Conservation
\end{tabular}

\section{Introduction}

India is one of the largest heritage resources for marine fishery resources. In India, there are nearly 1570 species of known marine fishes with the exploited area of 2.02 million sq.km of the Exclusive Economic Zone (EEZ). Also, Indian seas have many unexploited habitats like mesopelagic zone and deep
Cardinalfishes belongs to the family, Apogonidae is cryptic in nature that often shows taxonomic ambiguity through conventional taxonomy. It is globally accepted that mitochondrial DNA marker i.e., Cytochrome C Oxidase (COI) can be used to resolve these taxonomic uncertainties. In the present study, the DNA barcode was developed using COI marker for the two species of cardinalfishes (Archamia bleekeri and Ostorhinchus fleurieu) collected from Thoothukudi coast. Results showed that the distance values between the two species are higher than that of within the species. The Cytochrome $\mathrm{C}$ Oxidase subunit I (COI) gene showed more number of transitional pairs ( $\mathrm{Si}$ ) than transversional pairs ( $\mathrm{Sv}$ ) with a ratio of 2.4. The average distance values between A. bleekeri and $O$. fleurieu were $3.825,4.704,5.145,7.390,8.148,7.187$ and distance values among the A. bleekeri and $O$. fleurieu were 4.777 and 3.660, 3.583 and 6.509 respectively using K2P parameter. The average nucleotide frequency calculated were $\mathrm{A}=26.9 \%, \mathrm{~T}(\mathrm{U})=24.3 \%, \mathrm{C}=21.95 \%$ and $\mathrm{G}=26.8 \%$. The estimated GC content of A. bleekeri and O. fleurieu was (49.9\%) and (47.6\%) respectively and the average GC content was found to be $48.75 \%$. Phylogenic trees were constructed individually for the two species using MEGA 6.0 software and the Neighbour-Joining tree showed distinct clusters shared by the species of same genera. In conclusion, the present study developed DNA barcode database for the two species of cardinal fishes that can be used for taxonomic purposes for these species. 
Islands (Murty et al., 1989 and Vijayan and Varghese, 1990). In Tamil Nadu, Gulf of Mannar Ecosystem (GOME) covers an area spread over Rameswaram and Kanyakumari to about 19,000 $\mathrm{km}^{2}$. GOME lies between $78^{\circ} 11^{\prime} 00^{\prime \prime} \mathrm{E}$ and $79^{\circ} 15^{\prime} 00^{\prime}$ " E longitude and $8^{\circ} 49^{\prime} 00^{\prime \prime} \mathrm{N}$ and $9^{\circ} 15^{\prime} 00^{\prime \prime} \mathrm{N}$ latitude. The Gulf of Mannar in the southeast coast of India features a chain of 21 islands fringed with coral reefs, housing a variety of reef-dwelling fishes (Biswas et al., 2012). According to earlier authors, the predominant marine ornamental fishes are clowns, damsels, wrasses, surgeon fishes, butterfly fish, cardinals, and angels (Bamaniya et al., 2015). Eschmeyer (2014) reported 347 valid species under 38 valid genera in cardinalfishes around the world. In Tamil Nadu, over the past decade, there are about 33 new descriptions of Apogonids has been reported (Koya et al., 2011). Joshi et al., (2016) has recorded 43 Apogonids from Gulf of Mannar Ecosystem, Tamil Nadu. The family Apogonidae is divided into four subfamily; Apogoninae (Gunther, 1859) (34 genera), Pseudamiinae (Smith, 1954) (1 genera, Pseudamia), Paxtoninae (Fraser and Mabuchi, 2014) (1 genera, Poxton) and Amioidinae (Fraser and Mabuchi, 2014) (2 genera, Amioides and Holapogon) (Mabuchi et al., 2014).

Fishes of these families are generally small bodied $(<100 \mathrm{~mm})$ and live or shelter within the branches of live coral colonies throughout their lives (Vivien, 1975). Nevertheless most of the cardinalfishes are smaller in size but few species like Coranthus polyacanthus, Cheilodipterus intermedius, C. macrodon and Holapogon maximus grow in larger sizes i.e. $>20 \mathrm{~cm}$ (Fraser, 1973).

To date, much of the finfishes have been identified based on classical taxonomy and DNA barcoding for fish identification was ineffectively utilized. The taxonomic ambiguity exists for several fish Genera / species, and a proper identification is imperative for management and trade. DNA barcoding using mitochondrial DNA markers can be used to identify marine fishes and resolve taxonomic ambiguity including discovery of new/cryptic species. Mitochondrial DNA have several advantage that make it well suited for large scale DNA (molecular) tagging because it has large number of copies and also have advantages of high mutation rate and small effective population size which make an informative genome for evolutionary patterns and processes. DNA barcoding provides accurate and automated species identification through molecular species identification based on standard region (Cytochrome c Oxidase subunit 1). One obvious advantage of DNA barcoding comes from the rapid acquisition of molecular data. When the reference DNA sequence library is available, new specimens and products can be identified by comparing their DNA barcode sequences with the barcode reference library.

Till date, some of the species belongs to the family Apogonidae were successfully barcoded form the other geographical locations of globe. Despite the practical advantages of DNA barcoding in fish species identification discussed above, no one to the best of author knowledge has barcoded the cardinalfish species occurring along the Thoothukudi coast. Therefore, the present study was carried out with the following objectives to develop DNA barcodes for cardinalfishes of Thoothukudi coastal waters and also to analyze the level and patterns of barcode divergence for these species.

\section{Materials and Methods}

\section{Collection and preservation of samples}

Tissue samples of Gon's cardinalfish (Fig. 1) and Flower cardinalfish (Fig. 2) were 
collected from Thoothukudi coast during September 2016 to March 2017. The specimens were caught approximately $15 \mathrm{Nm}$ Southeast of Thoothukudi fishing harbour, Gulf of Mannar at a depth ranged from 75 to $100 \mathrm{~m}\left(8^{\circ} 38^{\prime} 127^{\prime \prime} \mathrm{N}\right)$ and $\left(78^{\circ} 12^{\prime} 612^{\prime \prime} \mathrm{E}\right)$ by trawler. The above two species of Apogonids were collected from Southeast of Thoothukudi fishing harbour, Tamil Nadu, they were preserved in $10 \%$ formaldehyde solution in room temperature for long storage and detailed examination (species identification) and preserved in $99.9 \%$ ethanol for DNA analysis and for further molecular studies. The alcohol preserved samples were stored in deep freezer $\left(-20^{\circ} \mathrm{C}\right)$. Species identification was carried out with Traditional fish identification techniques.

\section{Morphometric and meristic characterization}

Morphometric and meristic study is the most common tools for measuring discreteness of the same species. Morphometric and meristic characterization was carried out for the two species by analyzing a total of 15 morphometric and 6 meristic characteristics of the fishes. The fishes were examined for the following morphometric and meristic parameters such as Total length (TL), Forked length (FL), Standard length (SL), Head length (HL), Maximum body depth (MBD), Pectoral fin length (PcFL), Pelvic fin length (PeFL), Dorsal fin length (DL), Anal fin length (AFL), Pre Pectoral length (PPL), Pre Pelvic length (PPeL), Pre Anal length (PAL), Snout length (SnL), Head depth (HD), Eye Diameter $(E D)$, First dorsal fin $\left(\mathrm{D}_{1}\right)$, Second dorsal fin $\left(\mathrm{D}_{2}\right)$, Pectoral fin rays, Pelvic fin, Anal fin, lateral line scales.

\section{Genetic analysis}

DNA was extracted from muscle tissue by Phenol-chloroform method of Kumar et al.,
(2007) with little modification and the presence of the DNA was confirmed by $1 \%$ agarose gel electrophoresis. A 652-bp segment was amplified from the mitochondrial COXI gene using primer COX-F $\left(5^{\prime}\right.$ - TCA ACC AAC CAC AAA GAC ATT GGC AC - 3') and COX-R (5' - TAG ACT TCT GGG TGG CCA AAG AAT CA - 3') (Ward et al., 2005). PCR amplification were performed by the PCR conditions and primers used by Pereira et al., (2014). Amplified PCR products were checked on $2 \%$ agarose gel and the bands developed were observed in a GelDoc (Alphaimager Mini, Bio Rad, USA) system and the images were stored. The molecular weight of the PCR products (652bp) were determined with 100bp DNA ladder. The DNA content in the PCR product was analyzed by using biophotometer for further analysis. The sequences of the PCR products of COXI were analyzed by Eurofins genomics India Pvt. Ltd, Bangalore, India. Then sequences of the two species were blasted individually for the comparison of global data base - National Center for Biotechnological Information (NCBI). Sequence analysis was also carried out using softwares like MEGA version 6.0 and $\mathrm{ABI}$ sequence scanner and Bio edit.

\section{Results and Discussion}

Morphology and coloration of cardinalfishes

\section{Archamia bleekeri}

Body ovate to elongate, moderately compressed. Eyes are large, their diameter exceeding snout length. Color in live silvery gray, translucent on body, variable amount of bright yellow pigment on head and body, most commonly on snout, jaws and throat; side of the snout sometimes with dark dots; black caudal spot pupil size or smaller; fins pale; diffuse orange stripe above anal fin base. 


\section{Ostorhinchus fleurieu}

Body elongate, compressed; preopercular ridge is smooth, posterior and ventral margin mostly serrate. Eyes are large, their diameter exceeding snout length. Caudal fin forked. Body coppery with iridescence in life, with large black mid lateral spot on posterior caudal peduncle expanding to broad blackish bar in adults that does not distinctly broaden dorsally and ventrally; broad blackish band from snout tip to eye, bordered (in live specimens) by blue line above and below; narrow brown streak present on maxilla; anal fin base with line of dark brown dashes.

\section{Morphometric characteristics}

Morphometric and meristic characterisation of the two cardinalfishes $(\mathrm{n}=30)$ viz., Gon's cardinalfish (Archamia bleekeri) and Flower cardinalfish (Ostorhinchus fleurieu) were carried out and the observations are shown in Table 1 and 2.

The average standard length was observed higher in Ostorhinchus fleurieu (6.80 \pm 0.77 $\mathrm{cm}$ ), followed by Archamia bleekeri (4.71 \pm $0.50 \mathrm{~cm})$. The average total length for $O$. fleurieu and A. bleekeri were observed as 9.08 $\pm 1.02 \mathrm{~cm}$ and $6.09 \pm 0.70 \mathrm{~cm}$ respectively.

The average forked length was observed higher in $O$. fleurieu $(7.57 \pm 0.89 \mathrm{~cm})$, followed by A. bleekeri $(5.10 \pm 0.61 \mathrm{~cm})$. The average head length $O$. fleurieu and $A$. bleekeri were observed as $2.34 \pm 0.31 \mathrm{~cm}$ and $1.42 \pm 0.13 \mathrm{~cm}$ respectively.

Body depth was more in O. fleurieu $(3.13 \pm$ $0.50 \mathrm{~cm})$, followed by A. bleekeri $(1.91 \pm$ $0.31 \mathrm{~cm}$ ). The average pectoral fin length was high in O. fleurieu $(1.81 \pm 0.22 \mathrm{~cm})$ and for $A$. bleekeri $1.23 \pm 0.20 \mathrm{~cm}$. The average pelvic fin length was high in $O$. fleurieu $(1.62 \pm 0.24$ $\mathrm{cm})$, followed by $A$. bleekeri $(0.87 \pm 0.17 \mathrm{~cm})$.
The average dorsal fin length was high in $O$. fleurieu $(3.58 \pm 0.45 \mathrm{~cm})$ followed by $A$. bleekeri $(2.19 \pm 0.32 \mathrm{~cm})$. The average anal fin length was noticed same in $O$. fleurieu and A. bleekeri $(1.73 \pm 0.24 \mathrm{~cm})$. The average prepectoral fin length was recorded higher in $O$. fleurieu $(2.60 \pm 0.35 \mathrm{~cm})$ and lower was recorded in A. bleekeri $(1.52 \pm 0.15 \mathrm{~cm})$. The average pre- pelvic fin length was recorded higher in $O$. fleurieu $(2.42 \pm 0.40 \mathrm{~cm})$, but lower was recorded in A. bleekeri (1.37 \pm 0.14 $\mathrm{cm})$. The average pre- anal fin length was noticed higher in $O$. fleurieu $(4.56 \pm 0.58 \mathrm{~cm})$, followed by A. bleekeri $(2.30 \pm 0.40 \mathrm{~cm})$. The average snout length observed higher in $O$. fleurieu was $0.65 \pm 0.15 \mathrm{~cm}$ and in A. bleekeri was $0.37 \pm 0.06 \mathrm{~cm}$. Head depth was more in O. fleurieu $(2.36 \pm 0.40 \mathrm{~cm})$, but lower was noticed in A. bleekeri $(1.33 \pm 0.21 \mathrm{~cm})$. The average eye diameter was recorded higher in $O$. fleurieu $(0.85 \pm 0.11 \mathrm{~cm})$ followed by $A$. bleekeri $(0.50 \pm 0.07 \mathrm{~cm})$. In the present study, the maximum values in the morphometric characters like Total length, forked length, standard length, head length, maximum body depth, pectoral fin length, pelvic fin length, dorsal fin length, pre pectoral length, pre pelvic length, pre anal length, snout length, head depth and eye Diameter were observed for $O$. fleurieu than A. bleekeri. Anal fin length was same among the two species under this study. Previously, these similar characters have been widely used by Gunther (1859) for identifying the Gon's cardinalfish (A. bleekeri) and Lacepede (1802) identified the Flower cardinalfish $(O$. fleurieu $)$.

\section{Meristic characteristics}

In the present study meristic characters observed were: First dorsal fin spines VI, Second dorsal fin I+9 (spine and rays), Pectoral fin rays 14-15, Pelvic fin I+5 (spine and rays), Anal fin II+15-16 (spine and rays) and lateral line scales 26-28. These results were in agreement to the findings of Gunther 
(1859) and Biswas et al., (2014) recorded the meristic characteristics of $A$. bleekeri as: First dorsal fin with VI spines, Second dorsal fin with I spine followed by 9 soft rays. Pectoral fins with 14 - 15 rays. Pelvic fins with I spine followed by 5 rays. Anal fins II spines with 15 - 16 rays. Lateral line scales $26-28$.

In the present study, meristic characters of $O$. fleurieu recorded were: First dorsal fin spines VII, Second dorsal fin I+9 (spine and rays), Pectoral fin rays 13-14, Pelvic fin I+5 (spine and rays), Anal fin II+8 (spine and rays) and lateral line scales 23-24. These results were similar to the findings of Joshi et al., (2016), Lacepede (1802), Gon and Randall (2003), Biswas et al., (2014) and Randall et al., (1990). In their study the meristic characteristics observed for $O$. fleurieu were as follows: First dorsal fin with VII spines. Second dorsal fin with I spine and 9 soft rays. Pectoral fins with13 - 14 rays. Pelvic fins with I spine followed by 5 rays. Anal fins with II spines and 8 rays. Lateral line comprising 23 24 scales.

\section{Genetic analysis}

The total genomic DNA was isolated from the 5 individuals of each species of cardinalfishes following phenol-chloroform method (Kumar et al., 2007) with minor modifications in the present study. DNA isolated from all the individuals of two cardinalfishes were of good quality and used for downstream applications of the study. This study revealed that the analysis of DNA technique is an alternative to the morphological identification of fish species (Sotelo et al., 2001).

The partial sequence of Cytochrome C Oxidase subunit I gene was amplified with PCR using primers and temperature conditions that the reaction mixture was initially denatured at $94^{\circ} \mathrm{C}$ for $2 \mathrm{~min}$ followed by 35 cycles $\left(94^{\circ} \mathrm{C}\right.$ for $30 \mathrm{sec}, 52^{\circ} \mathrm{C}$ for $40 \mathrm{sec}, 72^{\circ} \mathrm{C}$ for $1 \mathrm{~min}$ ) the reaction was then subjected to final extension at $72^{\circ} \mathrm{C}$ for $10 \mathrm{~min}$. The amplification of the COI gene was carried out by following the method described by Hubert et al., (2008). The mean total nucleotide length obtained in the present study was 652bp (Fig. 3 ), which is in agreement with the results of earlier workers (Hubert et al., 2008; Ferri et al., 2009; Ko et al., 2013; Ramadan and Baeshen, 2012; Pereira et al., 2014, but slightly varied from the results of Lakra et al., (2011) [i.e., 655bp]. The results of the present study are also in consistent with the earlier foreign workers (Steinke et al., 2009a, b; Shirak et al., 2016; Thacker and Roje, 2009) as well as Indian workers (Lakra et al., 2011; Bamaniya et al., 2015).

In PCR products, pure DNA possess the ratio of absorbance at $260 \mathrm{~nm}$ and $280 \mathrm{~nm}$ $\left(\mathrm{A}_{260} / \mathrm{A}_{280}\right)$ is $1.6-2.0$. Ratio of less than 1.6 is indicative of protein contamination. Purity and concentration of DNA in the PCR products were analyzed in the present study was recorded as $1.94(1.65-2.97)$ (at 260nm and 280nm) in A. bleekeri and 1.76 (1.66 1.85 ) in $O$. fleurieu (Table 3). The results were within the quality range for PCR products as reported by previous workers (Kumar et al., 2007 and Pereira et al., 2014).

\section{Sequencing Analysis of Data}

Bidirectional sequencing of PCR products were carried out using Sanger sequencing methodology in Eurofins genomics India Pvt. Ltd, Bangalore, India. The raw sequences of the species were viewed using $\mathrm{ABI}$ sequence scanner for quality reads. The raw sequences were edited and aligned using BIOEDIT sequence alignment version 7.0.5.2 (Hall, 1999). These edited sequences of A. bleekeri and $O$. fleurieu, were compared with available sequences from NCBI (http://www.ncbi.nlm.nih.gov) for confirmation. 


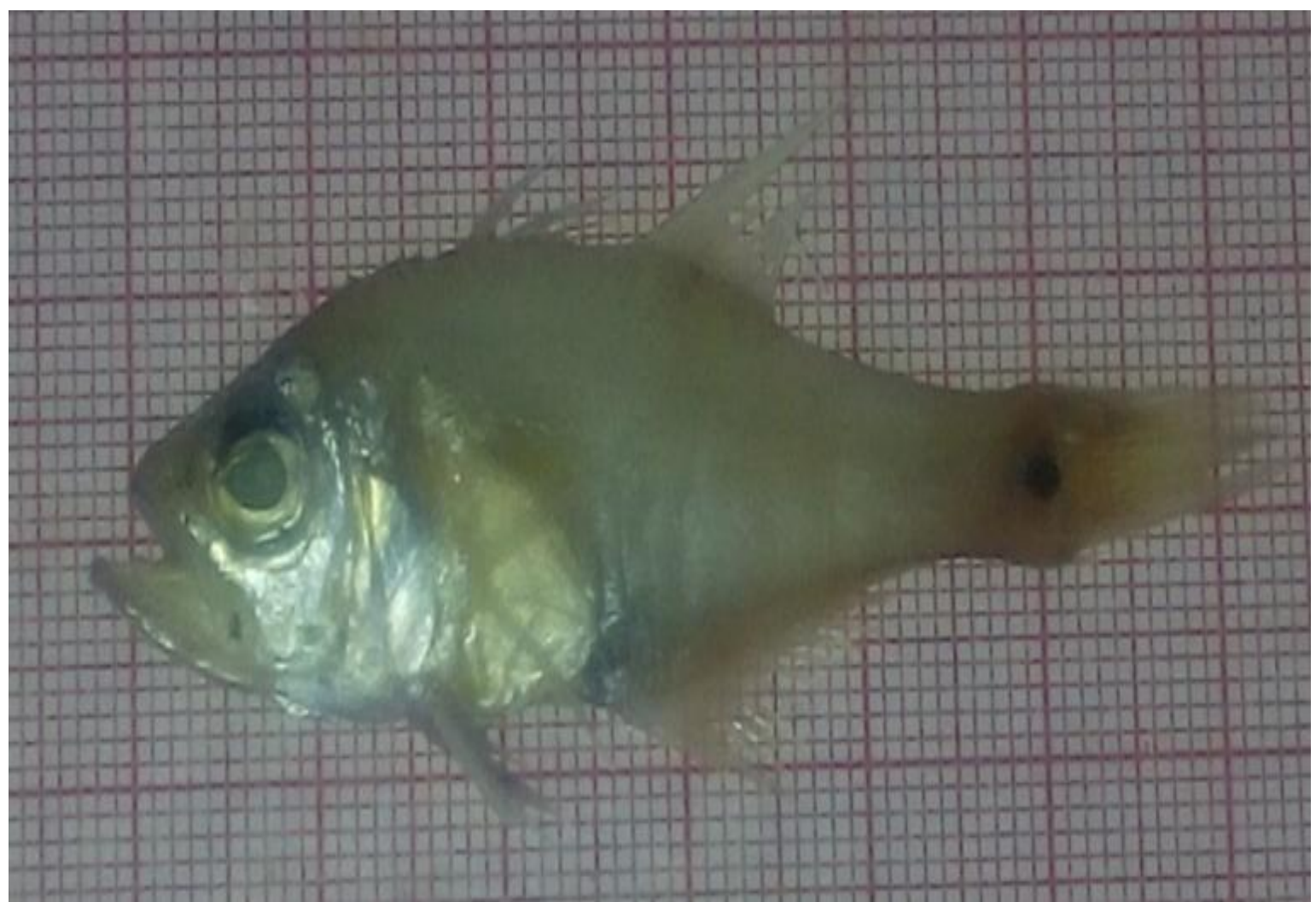

Fig.1 Archamia bleekeri

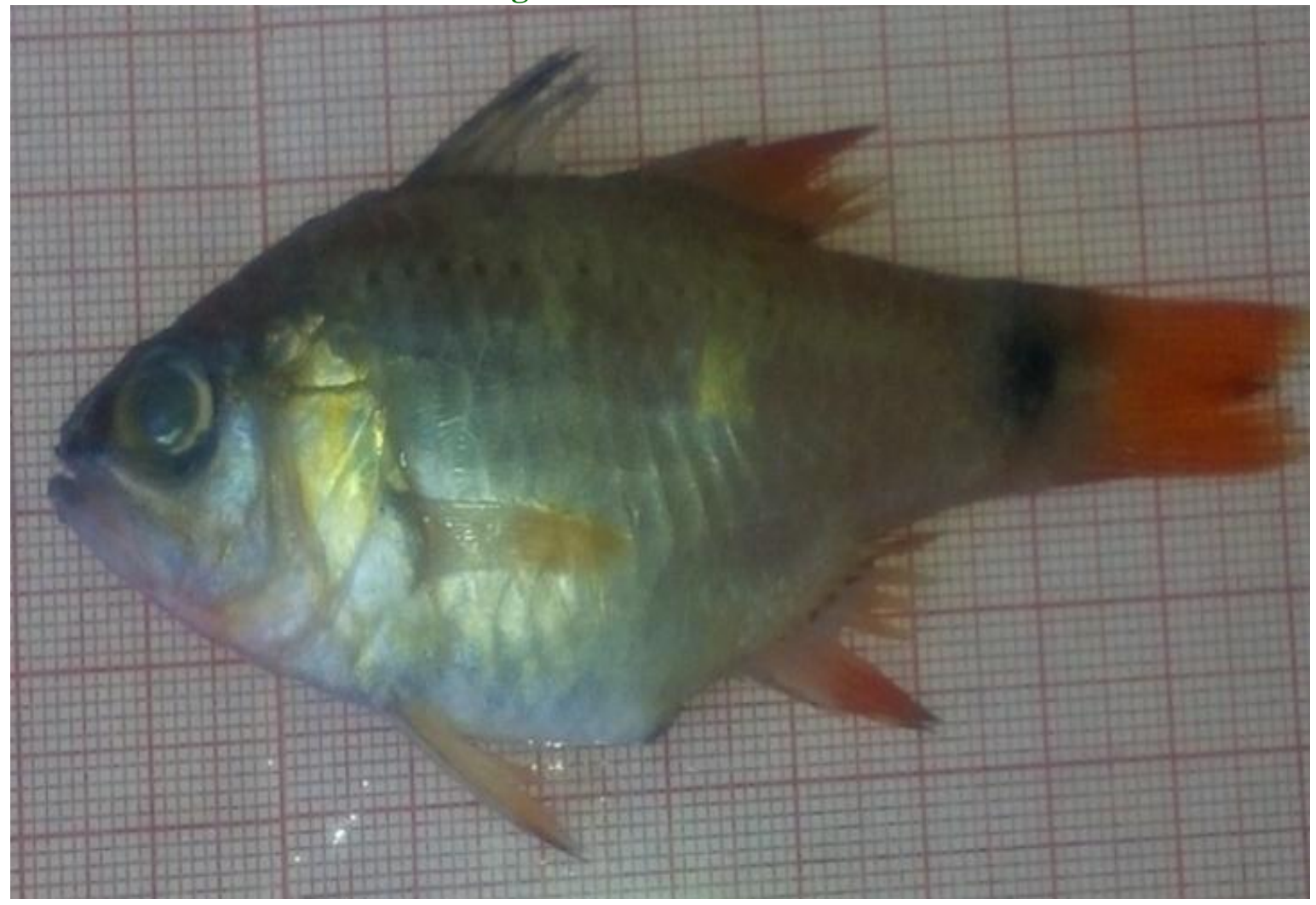

Fig.2 Ostorhinchus fleurieu 


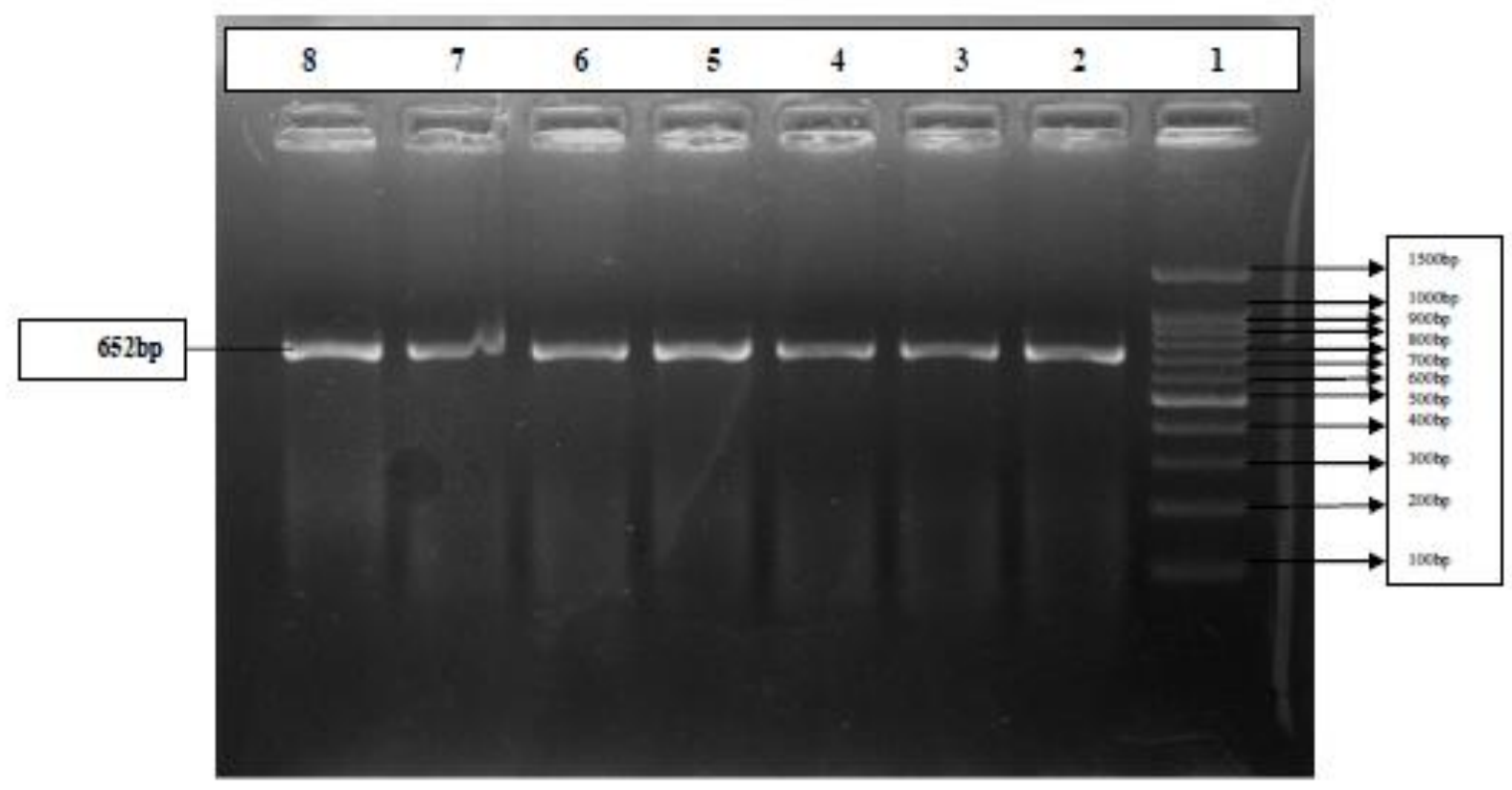

Fig 3 Amplified COI gene of Cardinalfishes

Lane 1: $100 \mathrm{bp}$ ladder

Lane 2: Positive control

Lane 3 to 5 : A. bleekeri

Lane 6 to 8: $O$. fleurien

Fig.4 Neighbour Joining (NJ) tree from the COI gene sequence data obtained from samples of cardinalfishes
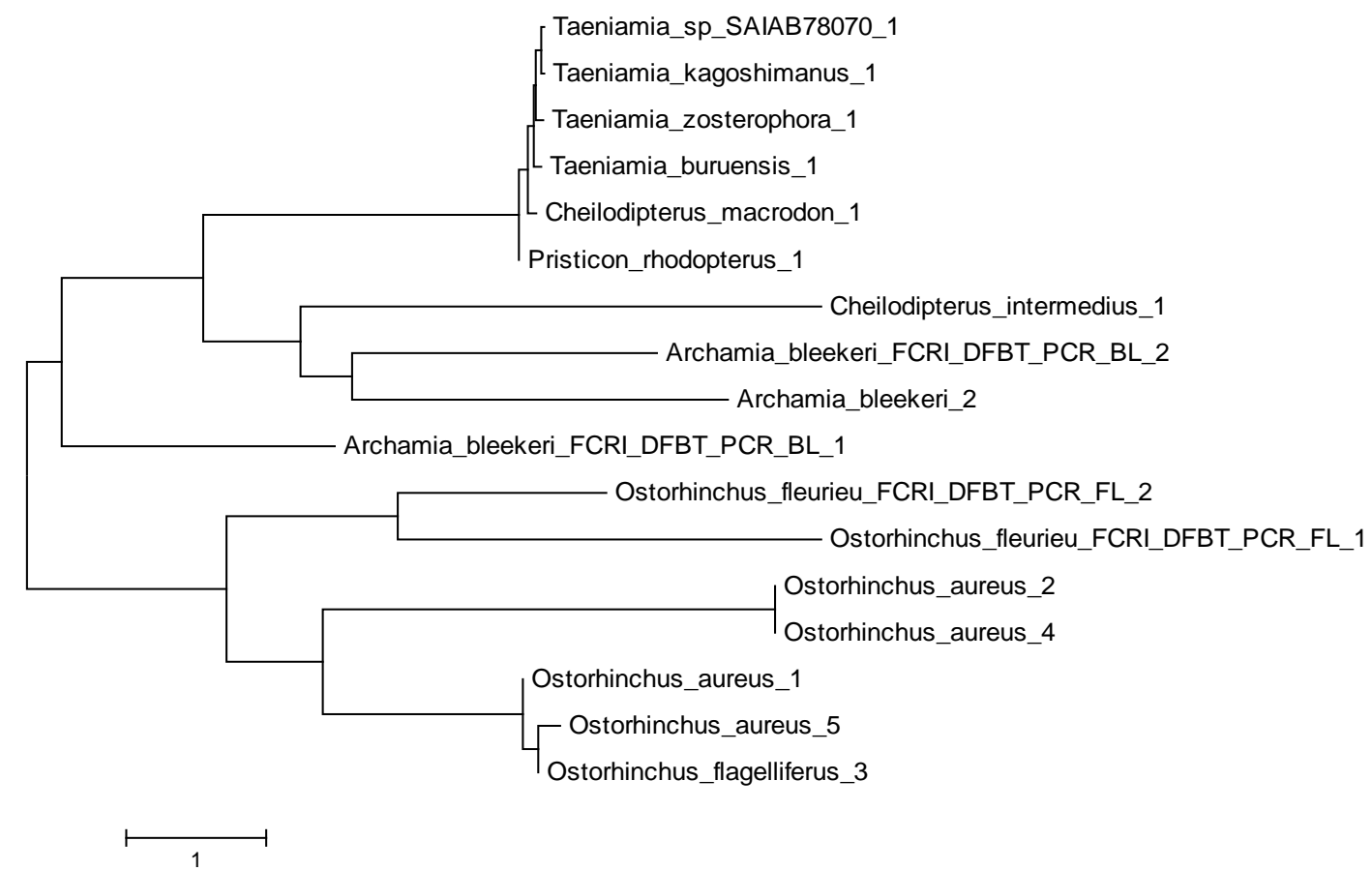
Table.1 Morphometric characters of cardinalfishes

\begin{tabular}{|c|c|c|c|c|c|}
\hline \multirow{2}{*}{$\begin{array}{l}\text { Sl. } \\
\text { No }\end{array}$} & \multirow{2}{*}{$\begin{array}{l}\text { Morphometric } \\
\text { characters }\end{array}$} & \multicolumn{2}{|c|}{ Archamia bleekeri $(\mathrm{n}=30)$} & \multicolumn{2}{|c|}{ Ostorhinchus fleurieu $(\mathrm{n}=30)$} \\
\hline & & Range $(\mathrm{cm})$ & Mean \pm SD $(\mathrm{cm})$ & Range $(\mathrm{cm})$ & Mean \pm SD $(\mathrm{cm})$ \\
\hline 1. & Standard length & $3.90-5.90$ & $4.71 \pm 0.50$ & $5.50-8.30$ & $6.80 \pm 0.77$ \\
\hline 2. & Total length & $5.00-7.40$ & $6.09 \pm 0.70$ & $7.30-11.0$ & $9.08 \pm 1.02$ \\
\hline 3. & Forked length & $4.20-6.40$ & $5.10 \pm 0.61$ & $6.0-9.20$ & $7.57 \pm 0.89$ \\
\hline 4. & Head length & $1.20-1.70$ & $1.42 \pm 0.13$ & $1.80-3.20$ & $2.34 \pm 0.31$ \\
\hline 5. & Body depth & $1.40-2.80$ & $1.91 \pm 0.31$ & $2.0-4.0$ & $3.13 \pm 0.50$ \\
\hline 6. & Pectoral Fin length & $0.80-1.80$ & $1.23 \pm 0.20$ & $1.30-2.30$ & $1.81 \pm 0.22$ \\
\hline 7. & Pelvic Fin length & $0.60-1.20$ & $0.87 \pm 0.17$ & $1.10-2.10$ & $1.62 \pm 0.24$ \\
\hline 8. & Dorsal Fin length & $1.70-2.80$ & $2.19 \pm 0.32$ & $2.80-4.40$ & $3.58 \pm 0.45$ \\
\hline 9. & Anal Fin length & $1.20-2.30$ & $1.73 \pm 0.24$ & $1.30-2.40$ & $1.73 \pm 0.24$ \\
\hline 10. & Pre Pectoral length & $1.30-1.80$ & $1.52 \pm 0.15$ & $2.0-3.30$ & $2.60 \pm 0.35$ \\
\hline 11. & Pre Pelvic length & $1.10-1.70$ & $1.37 \pm 0.14$ & $1.80-3.60$ & $2.42 \pm 0.40$ \\
\hline 12. & Pre Anal length & $1.20-3.30$ & $2.30 \pm 0.40$ & $3.70-5.80$ & $4.56 \pm 0.58$ \\
\hline 13. & Snout length & $0.30-0.50$ & $0.37 \pm 0.06$ & $0.40-0.90$ & $0.65 \pm 0.15$ \\
\hline 14. & Head depth & $1.10-1.80$ & $1.33 \pm 0.21$ & $1.70-3.20$ & $2.36 \pm 0.40$ \\
\hline 15. & Eye diameter & $0.40-0.60$ & $0.50 \pm 0.07$ & $0.70-1.10$ & $0.85 \pm 0.11$ \\
\hline & atimata CD. St & ion & & & \\
\hline
\end{tabular}

Table.2 Meristic characters of Cardinalfishes

\begin{tabular}{|c|l|c|c|}
\hline Sl. No. & \multicolumn{1}{|c|}{ Meristic characters } & Archamia bleekeri & Ostorhinchus fleurieu \\
\hline $\mathbf{1 .}$ & First dorsal fin $\left(\mathrm{D}_{1}\right)$ & $\mathrm{VI}$ & $\mathrm{VII}$ \\
\hline $\mathbf{2 .}$ & Second dorsal fin $\left(\mathrm{D}_{2}\right)$ & $\mathrm{I}+9$ & $\mathrm{I}+9$ \\
\hline $\mathbf{3 .}$ & Pectoral fin rays & $14-15$ & $13-14$ \\
\hline $\mathbf{4 .}$ & Pelvic fin & $\mathrm{I}+5$ & $\mathrm{I}+5$ \\
\hline $\mathbf{5 .}$ & Anal fin & $\mathrm{II}+15-16$ & $\mathrm{II}+8$ \\
\hline $\mathbf{6 .}$ & lateral line scales & $26-28$ & $23-24$ \\
\hline
\end{tabular}


Table.3 Analysis of DNA concentration in the PCR products with Biophotometer

\begin{tabular}{|c|l|c|c|c|c|}
\hline \multirow{2}{*}{ Sl. No. } & \multirow{2}{*}{ Name of the species } & \multicolumn{2}{|c|}{$\mathbf{A}_{\mathbf{2 6 0 n m}} / \mathbf{A}_{\mathbf{2 8 0 n m}}$} & \multicolumn{2}{c|}{ DNA conc. (ng/ $\mathbf{\mu l})$} \\
\cline { 3 - 6 } & & Range & Average & Range & Average \\
\hline 1. & Archamia bleekeri & $(1.65-2.97)$ & 1.94 & $(415.8-612.4)$ & 508.7 \\
\hline 2. & Ostorhinchus fleurieu & $(1.62-1.73)$ & 1.65 & $(401.6-496.6)$ & 455.6 \\
\hline
\end{tabular}

Table.4 Nucleotide composition of cardinalfishes

\begin{tabular}{|c|c|c|c|c|c|c|c|c|c|c|c|c|c|c|c|c|c|c|c|c|}
\hline \multicolumn{21}{|l|}{ Domain: Data } \\
\hline & $\begin{array}{l}\mathbf{T} \\
(\mathbf{U})\end{array}$ & $\mathbf{C}$ & $\mathbf{A}$ & $\mathbf{G}$ & Total & $\begin{array}{l}\text { T- } \\
1\end{array}$ & C-1 & A-1 & G-1 & $\begin{array}{l}\text { Pos } \\
\# 1\end{array}$ & $\begin{array}{l}\text { T- } \\
2\end{array}$ & $\mathrm{C}-2$ & A-2 & G-2 & $\begin{array}{l}\text { Pos } \\
\# 2\end{array}$ & T- & $\mathrm{C}-3$ & A-3 & G-3 & $\begin{array}{l}\text { Pos } \\
\# 3\end{array}$ \\
\hline Archamia_bleekeri_FCRI_DFBT_PCR_BL_1 & 21.9 & 19.9 & 27.6 & 30.7 & 704.0 & 15 & 14.5 & 40.0 & 30.2 & 235.0 & 28 & 30.6 & 16.2 & 25.1 & 235.0 & 22 & 14.5 & 26.5 & 36.8 & 234.0 \\
\hline Archamia_bleekeri_FCRI_DFBT_PCR_BL_2 & 28.5 & 30.2 & 22.3 & 19.1 & 692.0 & 18 & 26.4 & 26.4 & 29.4 & 231.0 & 42 & 28.1 & 16.9 & 13.4 & 231.0 & 26 & 36.1 & 23.5 & 14.3 & 230.0 \\
\hline Avg. & 25.1 & 25.0 & 24.9 & 24.9 & 698.0 & 17 & 20.4 & 33.3 & 29.8 & 233.0 & 35 & 29.4 & 16.5 & 19.3 & 233.0 & 24 & 25.2 & 25.0 & 25.6 & 232.0 \\
\hline \multirow[t]{2}{*}{ Mean } & 25.2 & 25.0 & 24.9 & 24.9 & \multicolumn{3}{|c|}{ Avg GC $=49.9 \%$} & & & & & & & & & & & & & \\
\hline & $\begin{array}{l}\mathbf{T} \\
(\mathbf{U})\end{array}$ & C & $\mathbf{A}$ & $\mathbf{G}$ & Total & $\begin{array}{l}\text { T- } \\
1\end{array}$ & C-1 & A-1 & G-1 & $\begin{array}{l}\text { Pos } \\
\# 1\end{array}$ & $\begin{array}{l}\text { T- } \\
2\end{array}$ & $\mathrm{C}-2$ & A-2 & G-2 & $\begin{array}{l}\text { Pos } \\
\# 2\end{array}$ & $\begin{array}{l}\text { T- } \\
3\end{array}$ & C-3 & A-3 & G-3 & $\begin{array}{l}\text { Pos } \\
\# 3\end{array}$ \\
\hline $\begin{array}{l}\text { Ostorhinchus_fleurieu_FCRI_DFBT_PCR_F } \\
\text { L_1 }\end{array}$ & 23.2 & 18.5 & 28.9 & 29.4 & 714.0 & 15 & 13.9 & 40.3 & 30.7 & 238.0 & 27 & 30.3 & 16.0 & 26.9 & 238.0 & 28 & 11.3 & 30.3 & 30.7 & 238.0 \\
\hline $\begin{array}{l}\text { Ostorhinchus_fleurieu_FCRI_DFBT_PCR_F } \\
\text { L_2 }\end{array}$ & 23.5 & 19.0 & 29.0 & 28.5 & 710.0 & 27 & 12.2 & 31.6 & 29.1 & 237.0 & 17 & 14.8 & 39.2 & 29.1 & 237.0 & 27 & 30.1 & 16.1 & 27.1 & 236.0 \\
\hline $\begin{array}{l}\text { Ostorhinchus_fleurieu_FCRI_DFBT_PCR_F } \\
\text { L_3 }\end{array}$ & 23.6 & 19.2 & 28.9 & 28.3 & 707.0 & 28 & 30.5 & 16.1 & 25.8 & 236.0 & 28 & 11.9 & 30.5 & 29.2 & 236.0 & 15 & 15.3 & 40.0 & 29.8 & 235.0 \\
\hline Avg. & 23.5 & 18.9 & 28.9 & 28.7 & 710.3 & 23 & 18.8 & 29.4 & 28.6 & 237.0 & 24 & 19.0 & 28.6 & 28.4 & 237.0 & 23 & 18.9 & 28.8 & 29.2 & 236.3 \\
\hline Mean & 23.5 & 19.0 & 28.9 & 29.0 & \multirow{2}{*}{\multicolumn{3}{|c|}{ Avg GC $=47.6 \%$}} & & & & & & & & & & & & & \\
\hline Final Avg & 24.3 & 22.0 & 26.9 & 26.8 & & & Avg GC $=48.75 \%$ & & & & & & & & & & & & & \\
\hline
\end{tabular}

Table.5 Genetic divergence values for A. bleekeri and O. fleurieu

\begin{tabular}{|l|c|c|c|c|}
\hline Species & $\mathbf{1}$ & $\mathbf{2}$ & $\mathbf{3}$ & $\mathbf{4}$ \\
\hline Archamia_bleekeri_FCRI_DFBT_PCR_BL_1 & & & & \\
\hline Archamia_bleekeri_FCRI_DFBT_PCR_BL_2 & 4.777 & & & \\
\hline Ostorhinchus_fleurieu_FCRI_DFBT_PCR_FL_1 & 3.825 & 7.390 & & \\
\hline Ostorhinchus_fleurieu_FCRI_DFBT_PCR_FL_2 & 4.704 & 8.148 & 3.660 & \\
\hline Ostorhinchus_fleurieu_FCRI_DFBT_PCR_FL_3 & 5.145 & 7.187 & 6.509 & 3.583 \\
\hline
\end{tabular}


Phylogenic and genetic divergence analyses including nucleotide characteristics were carried out using Molecular Evolutionary Genetics Analysis (MEGA version 6.0) (Tamura et al., 2013).

The nucleotide sequences of A. bleekeri (Acc. No. MF401074) were analyzed using BLAST and compared with global database. It was noticed that A. bleekeri exhibited 99\% homology with A. bleekeri having Acc. No. KU943595 (Chang et al., 2016). The sequence of $A$. bleekeri of this study was exhibited $86 \%$ homology with Taeniamia zosterophora (Acc. No. AB890113) (Mabuchi et al., 2013), Cheilodipterus macrodon (Acc. No. AB890037) (Mabuchi et al., 2013), Pristicon rhodopterus (Acc. No. AB890095) (Mabuchi et al., 2013), C. intermedius (Acc. No. KJ202144) (Ordonio et al., 2014) and $T$. buruensis (Acc. No. AB890109) (Mabuchi et al., 2013). A. bleekeri DNA sequence was also recorded $85 \%$ genetic relatedness with Taeniamia sp (Acc. No. AB890112) (Mabuchi et al., 2013), T. kagoshimanus (Acc. No. AB890111) (Mabuchi et al., 2013).

DNA sequences of $O$. fleurieu (Acc. No. MF401072) exhibited $99 \%$ of genetic relatedness with, A. aureus (Acc. No. JF492845) (Steinke et al., 2011) and $A$. erythrinus (Acc. No.KU943671) (Chang et al., 2016). It also exhibited 95\% homology with O. aureus (Acc. No. JQ349714) (Hubert et al., 2012) and $O$. aureus (Acc. No. JQ349713) (Mabuchi et al., 2013).

The sequence of $O$. fleurieu was identical with $94 \%$ genetic relatedness with $O$. aureus (Acc. No. AB890057, Hubert et al., 2012 and Acc. No. KF930210, Bentley and Wiley, 2013) and it also exhibited 92\% homology with A. flagelliferus (Acc. No. FJ346799) (Thacker and Roje, 2008) and 91\% genetic relatedness with $O$. flagelliferus (Acc. No.AB890065) (Mabuchi et al., 2013).

\section{Nucleotide sequence analysis}

According to Hajibabaei et al., (2006) DNA barcodes of $200-300 \mathrm{bp}$ nucleotide length be effective in identifying specimens. In the present study, the COI sequences of cardinalfish individuals were aligned and obtained the nucleotide sequence length of 227bp, 330bp for A. bleekeri and 369bp, $372 \mathrm{bp}$ and $336 \mathrm{bp}$ for $O$. fleurieu. The steps followed in the present study are agreed with the results of Hajibabaei et al., (2006). In the present study, Sequences of the two species of cardinalfishes were generated and deposited in GenBank under accession numbers MF401074 and MF401075 for A. bleekeri, MF401071, MF401072 and MF401073 for $O$. fleurieu using the submission tool Banklt.

In the present study, the mean GC content was obtained for A. bleekeri $=49.9 \%$ and $O$. fleurieu $=47.6 \%$. The average GC content $(48.75 \%)$ was similar to the findings of Ward et al., (2005) in teleost's (47.1\%). Similar reports were also obtained by Lakra et al., (2011) i.e., $51.2 \%$ in seventeen fish species of 13 genera of Carangidae, $48.5 \%$ in eleven fish species of Clupeidae and Engraulidae, $47.5 \%$ in six genera of Scombridae and $46.6 \%$ in seven species under the genus Epinephelus of Serranidae. Rathipriya (2016) observed $43.5 \%$ average GC content in 3 species of flying fishes. The results obtained in the present study are agreed with the results of following authors (Lakra et al., 2011 and Rathipriya, 2016).

The present analysis revealed the mean total nucleotide composition in A. bleekeri was $\mathrm{T}(\mathrm{U})=25.2, \mathrm{C}=25.0, \mathrm{~A}=24.9$ and $\mathrm{G}=24.9$ and in O. fleurieu was $\mathrm{T}(\mathrm{U})=23.5, \mathrm{C}=19.0$, $\mathrm{A}=28.9$ and $\mathrm{G}=29.0$ (Table 4). In the present study, the average nucleotide frequencies of the data set were $\mathrm{A}=26.9 \%, \mathrm{~T}(\mathrm{U})=24.3 \%$, $\mathrm{C}=21.95 \%$ and $\mathrm{G}=26.8 \%$. The similar results were also obtained by Lakra et al., (2011) i.e., 
$\mathrm{A}=23.3 \%, \mathrm{~T}(\mathrm{U})=28.2 \%, \mathrm{C}=28.5 \%$ and $\mathrm{G}=$ 20.0\% in eleven fish species of Clupeidae and Engraulidae, Persis et al., (2009) obtained A= $26.8 \%, \mathrm{~T}(\mathrm{U})=27.2 \%, \mathrm{C}=23.6 \%, \mathrm{G}=22.4 \%$ in carangid fishes and Rathipriya (2016) recorded $\mathrm{A}=30 \%, \mathrm{~T}(\mathrm{U})=26.40 \%, \mathrm{C}=17.0 \%$, $\mathrm{G}=26.6 \%$ in three species of flying fishes.

Pairwise evolutionary distance among haplotypes and tree construction was determined by the Kimura-2-Parameter method (Kimura, 1980) using the software program MEGA 6.0 (Molecular Evolutionary Genetics Analysis) (Kumar et al., 2004).

According to Page and Holmes, 1998 and Ward et al., 2005 typically observed larger excess of transitions related to transversion in mtDNA (i.e., transition /transversion ratio is above 2). In the present study the estimated transition /transversion bias( $\mathrm{R})$ of 2.44 is having agreement with Page and Holmes, 1998 and Ward et al., 2005.

Ward et al., (2005) and Lakra et al., (2011) found the transition /transversion ratios $>2$ in teleosts and the similar results were recorded in cardinalfishes in this study.

\section{Genetic divergence analysis}

The genetic distance between the individuals of $A$. bleekeri was estimated. It was found as 4.777. In the case of $O$. fleurieu, genetic distance between the individuals (FL_1 FL_2) was found as 3.660. It also exhibits the genetic distance between the individuals (FL_2 - FL_3) was 3.583 and (FL_1 - FL_3) was 6.509. The genetic distance between $A$. bleekeri and $O$. fleurieu was found as 3.825 (BL_1 - FL_1), 4.704 (BL_1 - FL_2), 5.145 (BL_1 - FL_3), 7.390 (BL_2 - FL_1), 8.148 (BL_2 - FL_2) and 7.187 (BL_2 - FL_3) respectively (Table 5). The pairwise genetic distance values were based on COXI sequences calculated using MEGA 6.0.
In the present study, Kimura-2-Parameter method was adapted to estimate genetic divergence. Hebert et al., (2004) revealed that the genetic divergence values between the species were well above the cut off value (2) reported in cardinalfishes in the present study.

This study was also reinforced the $\mathrm{R}$ value is higher than 2, the sequence substitutions are far from the saturation state that of Simon et al., (1994). So the transition /transversion ratio among the closely related species is higher than that among the distantly related species. Similar value was obtained by Lakra et al., (2011), Basheer et al., (2015), Bineesh et al., (2015), Pereira et al., (2014) and Rathipriya (2016) in different fish species.

\section{Phylogenetic tree analysis}

The Neighbour Joining (NJ) trees of K2P distance were generated to provide graphic representation using MEGA 6.0.

According to Ward et al., (2005), the phylogenetic relationship among the species was clearly established, Congeneric species always clustered together and the confamilial species always separately clustered.

The present study also indicating the above concept of bringing the species of same genus in a cluster and where in species of different genera were grouped in a separate cluster and similar results were registered by Basheer et al., (2015), Bineesh et al., (2015) and Rathipriya (2016) in marine fish species of Indian waters and Pereira et al., (2017) in native loaches.

The phylogenic relationship among the species was clearly established and closely related species were clustered under the same node while dissimilar species were clustered under separate nodes. The Neighbour Joining (NJ) trees were generated using MEGA 6.0. 
Taeniamia buruensis, T. zosterophora, $T$. kagoshimanus, Cheilodipterus macrodon and Pristicon rhodopterus sequences were distantly related with Archamia bleekeri_FCRI_DFBT_PCR_BL_2. So they were under another node and $C$. intermedius was closely related, but Archamia bleekeri_2 was very closely related with Archamia bleekeri_FCRI_DFBT_PCR_BL_2, so they were under same node. But $A$. bleekeri_FCRI_DFBT_PCR_BL_1 was distantly related with Archamia bleekeri_2 and also distantly related $O$. fleurieu_FCRI_DFBT_PCR_FL_1.

Ostorhinchus fleurieu_FCRI_DFBT_PCR FL_1 was very closely related with Ostorhinchus fleurieu_FCRI_DFBT_PCR_ FL_2, so they were under same node of the phylogenetic tree. $O$. aureus_4 and $O$. aureus_2 closely related with $O$. aureus_1, $O$. aureus_5 and $O$. flagelliferus_3. But these sequences were distantly related with $O$. fleurieu_FCRI_DFBT_PCR_FL_1, so they were comes under the separate clade of the phylogenetic tree. Tree generated using Neighbour Joining (NJ) algorithm depicted the species, $O$. fleurieu of the different individuals in sister clades and the species belonging to the different genus, A. bleekeri in a separate clade indicating the evolutionary relationship in accurate manner for the cardinalfish species under study (Fig. 4).

In conclusion, DNA barcodes were analyzed for the two species of cardinalfishes. The present study will help to the further studies on apogonids such as, species identification and further research on species diversity, population analysis of the cardinalfishes.

\section{Acknowledgement}

I wish to extend my sincere thanks to the Dean, Faculty of Basic Sciences, OMR campus, Vanniyanchavadi and the Dean,
Fisheries College and Research Institute, Thoothukudi for providing necessary facility to carry out the part of my research work. I also wish to acknowledge TNFU for providing PG merit fellowship for helping me in financial assistances.

\section{References}

Bamaniya, D.C, Pavan-Kumar, A., Gireesh-Babu, P., Sharma, N., Reang, D., Krishna, G., Lakra, W. S., 2015. DNA barcoding of marine ornamental fishes from India. Mitochondrial DNA, Early Online: 1-5.

Basheer, V.S., Mohitha, C., Vineesh, N., Divya, P. R., Gopalakrishnan, A., Jena, J. K., 2015. Molecular phylogenetics of three species of the genus Rastrelliger using mitochondrial DNA markers. Mol. BioL. Rep. 42, 873879.

Bineesh, K. K., Mohitha, C., Vineesh, N., Basheer, V.S., Joselet, M., Pillai, N. K., Jena, J. K.., Gopalakrishnan, A., 2015. Molecular identification of three deepsea fish species of the genus Chelidoperca (Perciformes: Serranidae) from Indian waters. Indian J. Fish. 62, 104-108.

Biswas S., Mishra S.S., Das, N.P.I., Selvanayagam, M., Nayak, L., Satpathy, K.K., 2012. New records of four reefassociated fishes from east coast of India. Acta Ichthyol. Piscat. 42 (3): 253-258.

Biswas, S., Jahir Hussain, K., Das, N. P. I., Russell, B. C., Satpathy, K. K., Mishra, S. S.,2014. Imprint of monsoonal patterns on the fish assemblage in coastal waters of south-east India: a case study. Journal of Fish Biology (2014) 85, 773-799.

Eschmeyer, W. N., 2014. Genera, species, references. Electronic Version http://research.calacademy.org/research/icht hyology/catalog/fish catmain.asp. Accessed 10 March 2014.

Ferri, G., Alu, M., Corradini, B., Licata, M., Beduschi, G., 2009. Species identification through DNA barcodes. Genet. Testing. Mol. Biomarkers. 13: 1-6.

Fraser, T. H., 1973. Evolutionary significance of Holapogon, a new genus of cardinal fishes (Apogonidae), with a redescription of its 
type species, Apogon maximus. J.L.B. Smith Institute of Ichthyology, Special Publication No. 10:1-7.

Gon, O., J.E. Randall., 2003. A Review of the Cardinalfishes (Perciformes: Apogonidae) of the Rea Sea. SMITHIANA, Publications in Aquatic Biodiversity. Bulletin 1.

Hajibabaei, M., Singer, G. A. C., Hickey, D. A., 2006. Benchmarking DNA barcodes: an assessment using available primate sequences. Genome. 49, 851 -854.

Hall, T.A., 1999. Bioedit: a userfriendly biological sequence alignment editor and analysis program for windows 95/98/NT. Nucleic acids symposium series No. 41, 95 -98 .

Hebert, P. D. N., Stockle, M., Zemlak, T., Francis, C. M., 2004. Identification of birds through DNA barcodes. Plos. Bio. 2, 1657- 1668.

Hubert, N., Hanner, R., Holm, E., Mandrak, N. E., Taylor, E. et al., 2008. Identifying Canadian freshwater fishes through DNA barcodes. Plos One, 3(6), e2490.

Joshi, K. K., Sreeram, M. P., Zacharia, P. U., Abdussamad, E. M., Varghese, M., Mohammed Habeeb, O. M. M. J., Jayabalan, K., Kanthan, K. P., Kannan, K., Sreekumar, K. M., George, G., Varsha, M. S., 2016. Check list of fishes of the Gulf of Mannar ecosystem, Tamil Nadu, India. $J$. Mar. Biol. Ass. India, 58 (1).

Kimura, M., 1980. A simple method of estimating evolutionary rate of base substitutions through comparative studies of nucleotide sequences. Journal of Molecular Evolution, $16,111-120$.

Ko, H. L., Wang, Y. T., Chiu, T. S., Lee, M. A., Leu, M. Y., Chang, K. Z., Chen, W. Y., Shao, K. T. et al., 2013. Evaluating the Accuracy of Morphological identification of larval fishes by applying DNA barcoding. PLoS ONE, 8: e53451.

Koya, K. P. S., Akhilesh, K. V., Bineesh, K. K., 2011. New record of Titan cardinalfish, Holapogon maximus (Apogonidae) along the southwest coast of India. Mar Biodivers $\operatorname{Rec} 4(36): 1-2$.

Kumar, R., Singh, P. J., Nagapune, N. S., Kushwaha, B., Srivastava, S. K., Lakra, W.S., 2007. A non-invasive technique for rapid extraction of DNA from fish scales.
Ind. J. Exp. Biol. 45, 992-997.

Kumar, S., Tamura, K., Nei, M., 2004. MEGA3: integrated software for molecular evolutionary genetics analysis and sequence alignment. Briefings in Bioinformatics, 5, 150-163.

Lakra, W. S., Verma, M. S., Goswami, M., Lal, K. K., Mohindra, V., Punia, P., Gopalakrishnan, A., Singh, K. V., Ward, R. D., Hebert, P., 2011. DNA barcoding Indian marine fishes: DNA Barcoding. Molecular Ecology Resources, 11, 60-71.

Mabuchi, K., Fraser, T. H., Song, H., Azuma, Y., Nishida, M., 2014. Revision of the systematics of the cardinalfishes (Percomorpha: Apogonidae) based on molecular analyses and comparative reevaluation of morphological characters. Zootaxa 3846 (2): 151-203.

Murty, V. S., Kumaran, M., Lalmohan, R. S., 1989. Resources of ornamental fishes. In: marine living resources of the Union Territory of Lakshadweep, an indicative survey with suggestions for development. Bull Central Mar Fish Res Instit 43:46-64.

Page, R. D. M., Holmes, E. C., 1998. Molecular evaluation: a phylogenetic approach. Blackwell Science, London.

Pereira, J. J., Shakila, J. R., Ahilan, B., Jeya Shakila, R., Marx, K. K., Rajagopalasamy, C. B. T., Jenifer, A. A., 2017. DNA barcode database for dotted loach, Nemacheilus semiarmatus (Day, 1867). J. Aqua. Trop. $31,1-12$.

Pereira, J. J., Shakila, J. R., Ahilan, B., Marx, K. K., Rajagopalasamy, C. B. T., 2014. DNA barcode of tropical loach, Lepidocephalus thermalis (Valenciennes) of Tamil Nadu. Inter. Res. J. Nat. Appli. Sci. 1, 165 - 177.

Persis, M., Reddy, A., Rao, L. M., Khedkar, G. D., Ravinder, K., Nasruddin, K., 2009. COI (cytochrome oxidase-I) sequence based studies of Carangid fishes from Kakinada coast, India. Mol. Biol. Rep (2009) 36:1733-1740.

Ramadan, H. A., Baeshen, N. A., 2012. Biological Identifications through DNA barcodes. In: Lameed GA, editor. Biodiversity conservation and utilization in a diverse world, 1st ed. Croatia: InTech. p 109-28.

Randall, J.E., Fraser, T. H., Lachner, E. A., 1990. 
On the validity of the Indo-Pacific cardinalfish Apogon aureus (Lacepède) and A. fleurieu (Lacepède), with description of a related new species from the Red Sea. Memoires de la Societe linneenne de Paris, 103 (1): 39- 62.

Rathipriya, A., 2016. Molecular identification and phylogenetic relationship of flying fishes of Tamil Nadu coast. P.G. Thesis submitted to Tamil Nadu Fisheries University. Nagapattinam. 96p.

Shirak, A., Dor Seroussi, E., Ron, M., Hulata, G., Golani, D., 2016. DNA barcoding of fish species from the Mediterranean coast of Israel. Medit. Mar. Sci. 17(2), pp. 459 466.

Simon, C., Frati, F., Beckenbach, A., Crespi, B., Liu, H., Flook, P., 1994. Evolution, Weighting and Phylogenetic utility of mitochondrial gene sequences and a compilation of conserved polymerase chain reaction primers. Annals. Entomo. Soci. America. 87, 651-701.

Sotelo, C. G., Calo-Mata, P., Chapelo, M. J., Perez-Martin, R. I., Rehbein, H., Hold, G. L., Russell, V. J., Pryde, S., Quinteiro, J., Izquierdo, M., Rey-Mendez, M., Rosa, C., Santos, A. T., 2001. Identification of flatfish (Pleuronectiformes) species using DNA- based techniques. Journal of Agriculture and Food Chemistry. 49, 4562-
4569.

Steinke, D., Zemlak, T.S., Boutillier, J.A., 2009a. DNA barcoding Pacific Canada's fishes. Mar. Biol. 156, 2641-2647.

Steinke, D., Zemlak, T.S., Hebert, P.D.N., 2009b. Barcoding Nemo: DNA-based identifications for the ornamental fish trade. PLoS ONE, 4 (7), e6300. http://dx.doi.org/10.1371/ journal.pone. 0006300 .

Tamura, K., Stecher, G., Filipski, A., Kumar, S., 2013. MEGA6: Molecular Evolutionary Genetics Analysis version 6.0. Mol. Bio. Evol. 30, 2725 - 2729.

Thacker, C. E., Roje, D. M., 2009. Phylogeny of cardinalfishes (Teleostei: Gobiiformes: Apogonidae) and the evolution of visceral bioluminescence. Molecular Phylogenetics and Evolution, 52 (2009) 735-745.

Vijayan, P. E., Varghese, T. J., 1990. Notes on marine ornamental fishes from Lakshadweep. Seafood Export J 22:13-8.

Vivien, M. L., 1975. Place of apogonid fish in the food webs of a Malagasy coral reef. Micronesica 11(2):185-196.

Ward, R. D., Zemlak, T. S., Innes, B. H., Last, P. R., Hebert, P. D. N., 2005. DNA barcoding of Australia's fish species. Phil. Trans. Roy. Soc. Lond. B. 360, 1847 - 1857.

\section{How to cite this article:}

Rajeshkannan, R., J. Jaculine Pereira, K. Karal Marx, P. Jawahar, D. Kiruthiga Lakshmi and Devivaraprasad Reddy. 2019. DNA Barcoding on Cardinalfishes (Apogonidae) of Thoothukudi Coast. Int.J.Curr.Microbiol.App.Sci. 8(08): 1293-1306.

doi: https://doi.org/10.20546/ijcmas.2019.808.153 